\title{
The reliability and prognostic implications of a simplified bone age classification system for adolescent idiopathic scoliosis
}

\author{
L Dolan ${ }^{1 *}$, K Masrouha $^{1}, \mathrm{G}$ El-Khoury ${ }^{2}, \mathrm{~S}$ Weinstein ${ }^{1}$ \\ From 8th International Conference on Conservative Management of Spinal Deformities and SOSORT 2011 \\ Annual Meeting \\ Barcelona, Spain. 19-21 May 2011
}

\section{Background}

Sanders et al. [1,2] describe a simplified system for determining digital skeletal age (DSA) and its use in predicting the likelihood a curve will reach surgical magnitude. We assessed the inter-and intra-rater reliability and prognostic implications of this classification system using data from a multicenter trial of outcomes in AIS (BrAIST).

\section{Material and methods}

36 subjects were randomly selected. We determined the predicted prognosis by cross-classifying the DSA and Cobb angle using Sanders' estimates.

\section{Results}

Kappa coefficients ranged from 0.76 to 0.88 . For example, one rater's reading corresponded to a $0 \%$ risk of the curve reaching surgical magnitude, while the other rater's reading for the same subject corresponded to a $92 \%$ risk.

The high level of agreement in DSA found by Sanders et. al was replicated in this study, and would be considered "substantial" to "almost perfect" using widely applied standards [3] Despite this agreement, different prognoses were predicted for $11 \%$ of these subjects.

\section{Conclusions}

Clinicians and researchers should consider seeking a second review of the DSA (especially if it appears to be in the DSA 2 to 3 range), and the Cobb angle, prior to using it to make prognostic predictions and treatment decisions.

'University of lowa, Department of Orthopaedic Surgery, lowa City, IA 522421007, USA

Full list of author information is available at the end of the article
Author details

'University of lowa, Department of Orthopaedic Surgery, lowa City, IA 522421007, USA. ${ }^{2}$ University of lowa, Department of Radiology, lowa City, USA.

Published: 27 January 2012

\section{References}

1. Sanders JO, Browne RH, McConnell SJ, et al: Maturity assessment and curve progression in girls with Idiopathic Scoliosis. J Bone Joint Surg Am 2007, 89:64-73.

2. Sanders JO, Khoury JG, Kishan S, Browne RH, Mooney JF 3rd, Arnold KD, McConnell SJ, Bauman JA, Finegold DN: Predicting scoliosis progression from skeletal maturity: a simplified classification during adolescence. J Bone Joint Surg Am 2008, 90(3):540-53.

3. Landis JR, Koch GG: The measurement of observer agreement for categorical data. Biometrics 1977, 33:159-74.

doi:10.1186/1748-7161-7-S1-014

Cite this article as: Dolan et al:: The reliability and prognostic implications of a simplified bone age classification system for adolescent idiopathic scoliosis. Scoliosis 2012 7(Suppl 1):014.

Submit your next manuscript to BioMed Central and take full advantage of:

- Convenient online submission

- Thorough peer review

- No space constraints or color figure charges

- Immediate publication on acceptance

- Inclusion in PubMed, CAS, Scopus and Google Scholar

- Research which is freely available for redistribution 